\title{
First report of Angiostrongylus cantonensis (Nematoda: Metastrongylidae) in Achatina fulica (Mollusca: Gastropoda) from Southeast and South Brazil
}

\author{
Arnaldo Maldonado Júnior ${ }^{1 /+}$, Raquel O Simões ${ }^{1}$, Ana Paula M Oliveira ${ }^{2}$, \\ Esther M Motta ${ }^{3}$, Mônica A Fernandez ${ }^{2}$, Zilene M Pereira ${ }^{2,3}$, Simone S Monteiro' ${ }^{3}$, \\ Eduardo J Lopes Torres $^{5}$, Silvana Carvalho Thiengo ${ }^{2}$
}

\author{
'Laboratório de Biologia e Parasitologia de Mamíferos Silvestres Reservatórios ²Laboratório de Malacologia \\ ${ }^{3}$ Laboratório de Educação em Ambiente e Saúde ${ }^{4}$ Laboratório de Patologia, Instituto Oswaldo Cruz-Fiocruz, Av. Brasil 4365, 21040-900 \\ Rio de Janeiro, RJ, Brasil ${ }^{5}$ Laboratório de Biologia de Helmintos Otto Wucherer, Instituto de Biofísica Carlos Chagas Filho, \\ Universidade Federal do Rio de Janeiro, Rio de Janeiro, RJ, Brasil
}

\begin{abstract}
The rat lungworm Angiostrongylus cantonensis is a worldwide-distributed zoonotic nematode that can cause human eosinophilic meningoencephalitis. Here, for the first time, we report the isolation of A. cantonensis from Achatina fulica from two Brazilian states: Rio de Janeiro (specifically the municipalities of Barra do Pirai, situated at the Paraiba River Valley region and São Gonçalo, situated at the edge of Guanabara Bay) and Santa Catarina (in municipality of Joinville). The lungworms were identified by comparing morphological and morphometrical data obtained from adult worms to values obtained from experimental infections of A. cantonensis from Pernambuco, Brazil, and Akita, Japan. Only a few minor morphological differences that were determined to represent intra-specific variation were observed. This report of A. cantonensis in South and Southeast Brazil, together with the recent report of the zoonosis and parasite-infected molluscs in Northeast Brazil, provide evidence of the wide distribution of A. cantonensis in the country. The need for efforts to better understand the role of A. fulica in the transmission of meningoencephalitis in Brazil and the surveillance of molluscs and rodents, particularly in ports, is emphasized.
\end{abstract}

Key words: Angiostrongylus cantonensis - Achatina fulica - eosinophilic meningoencephalitis Rio de Janeiro - Santa Catarina - Brazil

The rat lungworm Angiostrongylus cantonensis is endemic in several parts of the world (Kliks \& Palumbo 1992, Wang at al. 2008). Human eosinophilic meningoencephalitis disease caused by this metastrongylid has been reported in southeast Asia (Tsai et al. 2001), the Pacific Islands (Alicata 1962, Rosen et al. 1967, Slom et al. 2002), North America (Diaz 2008) and South America (Caldeira et al. 2007, Lima et al. 2009, Thiengo et al. 2010).

This nematode has been reported to infect several different terrestrial and freshwater snail species as intermediate hosts, including Achatina Lissachatina fulica (Bowdich 1822) and Pomacea canaliculata (Lamarck 1822) (Liu et al. 2007). Rodents, including Rattus norvegicus and Rattus rattus, have been reported as natural definitive hosts in Africa (Yousif \& Ibrahim 1978, Foronda et al. 2010), Australia (Mackerras \& Sandars 1955, Bhaibulaya 1968), North America (Qvarnstrom et al. 2007, Diaz 2008) and some Asian countries (Lv et al. 2009). A. cantonensis infections in $A$. fulica have been reported in three Brazilian states: Espírito Santo (ES), São Paulo (Caldeira et al. 2007) and Pernambuco (PE) (Thiengo et al. 2010).

\footnotetext{
Financial support: CNPq, IOC-FIOCRUZ

+ Corresponding author: maldonad@ioc.fiocruz.br

Received 7 May 2010

Accepted 20 July 2010
}

In this study, $A$. fulica specimens were collected by health workers from two municipalities in the state of Rio de Janeiro (Barra do Piraí and São Gonçalo) and one municipality in the state of Santa Catarina (Joinville). These specimens were then examined for parasitism with $\mathrm{L}_{3}$ larvae of $A$. cantonensis in the Malacology Laboratory of Oswaldo Cruz Institute (IOC). In brief, the molluses were individually minced and digested in a $0.7 \% \mathrm{HCl}$ solution for $6 \mathrm{~h}$. The digested samples were then placed in a Baermann apparatus and allowed to sediment overnight. Out of $207 \mathrm{~A}$. fulica snails tested, 44 (21.2\%) presented infection with $\mathrm{L}_{3}$ larvae of $A$. cantonensis alone and $17(8.2 \%)$ presented a concomitant infection with Strongyluris or Rhabditis sp. The prevalences of infection are listed in Table I.

The $\mathrm{L}_{3}$ nematode larvae obtained from digested snails were administered orally to 3 -month-old $R$. norvegicus (Wistar strain) rats (100 L3/rodent). Thirty-five days after administration of the larvae, the rodents were euthanized using a $\mathrm{CO}_{2}$ chamber; adult worms were then collected from the pulmonary arteries, washed in physiologic solution and fixed in 2\% glacial acetic acid, 3\% formaldehyde and $95 \%$ ethanol (AFA) at $60^{\circ} \mathrm{C}$. Ten male and 10 female specimens from each isolate were cleared and mounted as temporary slides in lactophenol solution and examined under a light microscope; drawings for the morphometric analyses were then made with the aid of a camera lucida. Unless otherwise stated, all measurements are given in millimetres. Taxonomic identification of the nematodes was based on morphological 
and morphometric parameters obtained from previous studies (Chen 1935, Mackerras \& Sandars 1955, Alicata 1963, Yousif \& Ibrahim 1978). For comparison, specimens of $A$. cantonensis from Akita, Japan (Department of Parasitology, Medical School, Akita University, Japan) and A. cantonensis from PE (Thiengo et al. 2010), were also analyzed. Representative adult specimens of A. cantonensis were deposited in the Helminthological Collection of IOC under the following reference numbers: CHIOC 35702 (Barra do Piraí isolate: 2 males and 2 females), CHIOC 35703 (São Gonçalo isolate: 2 males and 2 females) and CHIOC 35704 (Joinville isolate: 1 male and 4 females).

The measurements of adult $A$. cantonensis are listed in Table II. The bursal rays of the São Gonçalo specimens were longer and thinner than those of the specimens from Japan and PE (Figure). The size of the spicules was very similar among the three isolated specimens (Table II). The bursal morphological characteristics of the Barra do Piraí specimens more closely matched specimens from Canton (Asia) (Chen 1935) and PE (Thiengo et al. 2010), whereas the São Gonçalo specimens more closely matched A. cantonensis from Africa (Yousif \& Ibrahim 1978). The particular characteristics of the caudal bursa and the spicule length allowed us to identify the studied specimens as $A$. cantonensis.

$R$. norvegicus is considered an exotic species in almost all continents except Asia, where it is native and has been found infected with $A$. cantonensis. The spread of this nematode to the North American continent has been attributed to the introduction of $R$. norvegicus carried in containers being transported on ships (Diaz 2008).

Helminthological surveys of wild rodents in South America have shown that sigmodontine rodents are the primary hosts for Angiostrongylus spp in the following cases: Angiostrongylus lenzii in Akodon montensis (Souza et al. 2009), Angiostrongylus morerai in Akodon azarae (Robles et al. 2008) and Angiostrongylus costaricensis in Oligoryzomys nigripes and Sooretamys angouya (syn. O. ratticeps) (Graeff-Teixeira et al. 1990).

TABLE I

Prevalence of infection in Achatina fulica snails by Angiostrongylus cantonensis, Strongyluris sp. and Rhabditis sp. from two Brazilian states

\begin{tabular}{|c|c|c|c|c|c|}
\hline \multirow[b]{2}{*}{ Local } & \multirow[b]{2}{*}{$\begin{array}{l}\text { Snails examined } \\
\mathrm{n}\end{array}$} & \multirow[b]{2}{*}{$\begin{array}{l}\text { A. cantonensis } \\
\text { (\% infected })\end{array}$} & \multicolumn{3}{|c|}{$\begin{array}{c}\text { Concomitant infections } \\
(\% \text { infected })\end{array}$} \\
\hline & & & $\begin{array}{c}\text { A. cantonensis } \\
+ \\
\text { Strongyluris sp. }\end{array}$ & $\begin{array}{c}\text { A. cantonensis } \\
+ \\
\text { Rhabditis sp. }\end{array}$ & $\begin{array}{c}\text { A. cantonensis } \\
+ \\
\begin{array}{c}\text { Strongyluris } \mathrm{sp} . \\
+ \\
\text { Rhabditis } \mathrm{sp} .\end{array}\end{array}$ \\
\hline \multicolumn{6}{|l|}{ Rio de Janeiro } \\
\hline São Gonçalo & 48 & 35.4 & 14.6 & - & 2.1 \\
\hline Barra do Piraí & 97 & 10.3 & 1.0 & 1.0 & - \\
\hline \multicolumn{6}{|l|}{ Santa Catarina } \\
\hline Joinville & 62 & 27.4 & - & 11.3 & - \\
\hline
\end{tabular}

measurements are presented in millimeters. Number of worms measured from each municipality: 10 males and 10 females.

A

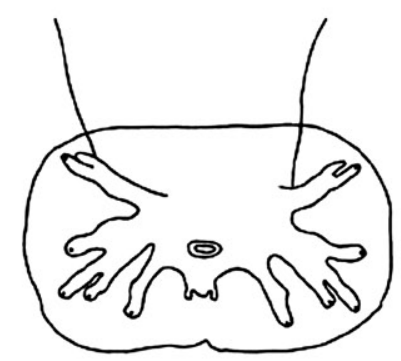

B

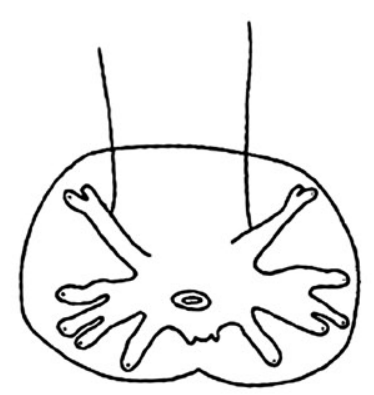

C

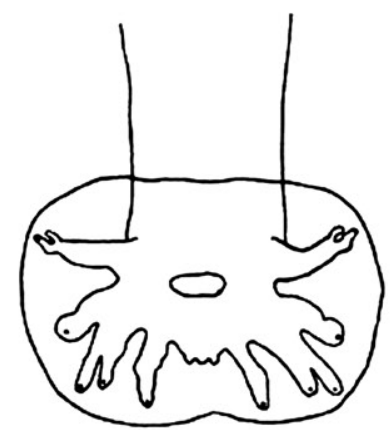

Light microscopy of Angiostrongylus cantonensis. A: A. cantonensis isolate from São Gonçalo, Rio de Janeiro (RJ). Ventral view of caudal bursa; B: A. cantonensis isolate from Barra do Piraí, RJ; C: A. cantonensis isolate from Joinville, Santa Catarina. Ventral view of caudal bursa. Bar $=50 \mu \mathrm{m}$. 


\section{TABLE II}

Morphometric data from pulmonary artery adults worms (10 males and 10 females) of Angiostrongylus cantonensis isolates from the municipalities of São Gonçalo and Barra do Piraí, Rio de Janeiro (RJ) and the municipality of Joinville, Santa Catarina (SC) after experimental infection of Rattus norvegicus (Wistar strain)

\begin{tabular}{|c|c|c|c|c|c|c|}
\hline \multirow{3}{*}{$\begin{array}{l}\text { States } \\
\text { Municipalities }\end{array}$} & \multicolumn{4}{|c|}{$\mathrm{RJ}$} & \multirow{2}{*}{\multicolumn{2}{|c|}{$\frac{\mathrm{SC}}{\text { Joinville }}$}} \\
\hline & \multicolumn{2}{|c|}{ São Gonçalo } & \multicolumn{2}{|c|}{ Barra do Piraí } & & \\
\hline & $\hat{0}$ & 우 & $\hat{0}$ & 우 & $\hat{\sigma}$ & 우 \\
\hline Body length & $19.40 \pm 1.99$ & $25.49 \pm 0.59$ & $18.48 \pm 0.45$ & $21.63 \pm 0.56$ & $15.39 \pm 0.88$ & $18.83 \pm 0.54$ \\
\hline Width & $0.32 \pm 0.01$ & $0.45 \pm 0.01$ & $0.26 \pm 0.01$ & $0.29 \pm 0.01$ & $0.26 \pm 0.2$ & $0.30 \pm 0.02$ \\
\hline Esophagus & $0.24 \pm 0.03$ & $0.28 \pm 0.01$ & $0.27 \pm 0.01$ & $0.29 \pm 0.01$ & $0.29 \pm 0.05$ & $0.30 \pm 0.03$ \\
\hline Nerve ring & $0.08 \pm 0.01$ & $0.06 \pm 0.01$ & $0.07 \pm 0.01$ & $0.06 \pm 0.01$ & $0.16 \pm 0.09$ & $0.15 \pm 0.08$ \\
\hline Excretory pore & $0.31 \pm 0.06$ & $0.37 \pm 0.01$ & $0.37 \pm 0.01$ & $0.41 \pm 0.01$ & $0.16 \pm 0.22$ & $0.48 \pm 0.15$ \\
\hline Spicules & $1.23 \pm 0.06$ & - & $1.25 \pm 0.01$ & - & $1.33 \pm 0.01$ & - \\
\hline Gubernaculum & $0.07 \times 0.02$ & - & $0.10 \times 0.01$ & - & $0.21 \times 0.03$ & - \\
\hline Vulva-tail & - & $0.15 \pm 0.01$ & - & $0.16 \pm 0.01$ & - & $0.22 \pm 0.06$ \\
\hline Anus-tail & - & $0.06 \pm 0.01$ & - & $0.06 \pm 0.004$ & - & $0.06 \pm 0.02$ \\
\hline Eggs & - & $0.08 \times 0.04$ & - & $0.05 \pm 0.03$ & - & $0.1 \times 0.06$ \\
\hline
\end{tabular}

However, no detailed information regarding the definitive hosts of $A$. cantonensis in South America is currently available. In Brazil, $\mathrm{L}_{1}$ larvae of $A$. cantonensis were isolated from the faeces of naturally infected $R$. norvegicus in ES (Caldeira et al. 2007), though the adult worm morphology was not described.

The wide distribution of $A$. cantonensis in Brazil is likely a result of multiple introductions of parasite-carrying rats during the country's colonial period, due to active commerce with Africa and Asia at that time. Together, the discovery of $A$. cantonensis in a municipality situated far from the coast in the Paraiba River Valley region and the observed intra-specific morphological variability of adult worms corroborate this hypothesis.

The rapid spread of $A$. fulica over the country (now having reached 24 out of 26 Brazilian states and the Federal District) is likely contributing to the dispersion of the parasite (Thiengo et al. 2010). This phenomenon is described in the literature as one of the primary causes of the spread of this zoonosis (Kliks \& Palumbo 1992, Lima et al. 2009, Lv et al. 2009).

Further studies to enhance understanding of the infection dynamics of $A$. cantonensis in natural vertebrate and invertebrate hosts could help elucidate the role of wild rodents and snails in the transmission of angiostrongyliasis.

The present report of $A$. cantonensis in Southeast and South Brazil broadens the reported distribution of this parasite in the country. From a public health perspective, it stresses the need for surveillance and control of $A$. $f u$ lica and rodents, particularly in and around ports.

\section{ACKNOWLEDGEMENTS}

To Dr. Carlos Graeff-Teixeira, from Laboratory of Molecular Parasitology and Parasite Biology, Pontifical Catho- lic University, Rio Grande do Sul, Brazil, who lent us Angiostrongylus cantonensis specimens from Akita, Japan, and to all the staff of the Secretarias Municipais de Saúde de Barra do Piraí and São Gonçalo (Rio de Janeiro) and Joinville (Santa Catarina), for collecting and sending specimens of Achatina fulica to our laboratory.

\section{REFERENCES}

Alicata JE 1962. Angiostrongylus cantonensis (Nematoda: Metastrongylidae) as a causative agent of eosinophilic meningitis of man in Hawaii and Tahiti. Can J Zool 40: 5-8.

Alicata JE 1963. Incapability of vertebrates to serve as paratenic host for the infective larvae of Angiostrongylus cantonensis. J Parasitol 49: 48.

Bhaibulaya M 1968. A new species of Angiostrongylus in an Australian rat, Rattus fuscipes. Parasitology 58: 789-799.

Caldeira RL, Mendonça CLG, Goveia CO, Lenzi HL, Graeff-Teixeira C, Lima WS, Mota EM, Pecora IL, Medeiros AMZ, Carvalho OS 2007. First record of molluscs naturally infected with $A n$ giostrongylus cantonensis (Chen, 1935) (Nematoda: Metastrongylidae) in Brazil. Mem Inst Oswaldo Cruz 102: 887-889.

Chen HT 1935. Un nouveau nématode pulmonaire, Pulmonema cantonensis n.g.n. sp. des rats de Canton. Ann Parasitol Hum Comp 13: 312-317.

Diaz JH 2008. Helminth eosinophilic meningitis: emerging zoonotic diseases in the South. J La State Med Soc 160: 333-342.

Foronda P, López-González M, Miguel J, Torres J, Segovia M, AbreuAcosta N, Casanova JC, Valladares B, Mas-Coma S, Bargues MD, Feliu C 2010. Finding of Parastrongylus cantonensis (Chen, 1935) in Rattus rattus in Tenerife, Canary Islands (Spain). Acta Trop 114: 123-127.

Graeff-Teixeira C, de Avila-Pires FD, Machado R de C, Camillo-Coura L, Lenzi HL 1990. Identificação de roedores silvestres como hospedeiros do Angiostrongylus costaricensis no sul do Brasil. Rev Inst Med Trop Sao Paulo 32: 147-150. 
Kliks MM, Palumbo NE 1992. Eosinophilic meningitis beyond the Pacific Basin: the global dispersal of a peridomestic zoonosis caused by Angiostrongylus cantonensis, the nematode lungworm of rats. Soc Sci Med 34: 199-212.

Lima AR, Mesquita SD, Santos SS, Aquino ER, Rosa L da R, Duarte FS, Teixeira AO, Costa ZR, Ferreira ML 2009. Alicata disease: neuroinfestation by Angiostrongylus cantonensis in Recife, Pernambuco, Brazil. Arq Neuropsiquiatr 67: 1093-1096.

Liu HX, Zhang Y, Lv S, Zhu D, Ang XH, Hu L, Zhou XN 2007. A comparative study of three methods in detecting Angiostrongylus cantonensis larvae in lung tissue of Pomacea canaliculata. Zhongguo Ji Sheng Chong Xue Yu Ji Sheng Chong Bing Za Zhi 25: 53-56.

Lv S, Zhang Y, Liu HX, Zhang CW, Steinmann P, Zhou XN, Utzinger J 2009. Angiostrongylus cantonensis: morphological and behavioral investigation within the freshwater snail Pomacea canaliculata. Parasitol Res 104: 1351-1359.

Mackerras MJ, Sandars DF 1955. The life history of the rat lung-worm Angiostrongylus cantonensis (Chen) (Nematoda: Metastrongylidae). Aust J Zool 3: 1-21.

Qvarnstrom Y, Sullivan JJ, Bishop HS, Hollingsworth R, da Silva AJ 2007. PCR-based detection of Angiostrongylus cantonensis in tissue and mucus secretions from molluscan hosts. Appl Environ Microbiol 73: 1415-1419.

Robles M del R, Navone GT, Kinsella JM 2008. A new angiostrongylid (Nematoda) species from the pulmonary arteries of Akodon azarae (Rodentia: Cricetidae) in Argentina. J Parasitol 94: 515-519.
Rosen L, Loison G, Laigart J, Wallace GR 1967. Studies on eosinophilic meningitis. 3. Epidemiologic and clinical observations on Pacific islands and the possible etiologic role of Angiostrongylus cantonensis. Am J Epidemiol 85: 17-44.

Slom TJ, Cortese MM, Gerber SI, Jones RC, Holtz TH, Lopez AS, Zambrano CH, Sufit RL, Sakolvaree Y, Chaicumpa W, Herwaldt BL, Johnson S 2002. An outbreak of eosinophilic meningitis caused by Angiostrongylus cantonensis in travelers returning from the Caribbean. N Engl J Med 346: 668-675.

Souza J, Simões R, Thiengo SA, Lima W, Mota E, Rodrigues-Silva R, Lanfredi RM, Maldonado Jr. A 2009. A new metastrongilidae species (Nematoda): a lungworm from Akodon montensis (Rodentia: Sigmodontinae) in Brazil. J Parasitol 95: 1507-1511.

Thiengo SC, Maldonado A, Mota EM, Torres EJ, Caldeira R, Carvalho OS, Oliveira AP, Simões RO, Fernandez MA, Lanfredi RM 2010. The giant African snail Achatina fulica as natural intermediate host of Angiostrongylus cantonensis in Pernambuco, northeast Brazil. Acta Trop 115: 194-199.

Tsai HC, Liu YC, Kunin CM, Lee SS, Chen YS, Lin HH, Tsai TH, Lin WR, Huang CK, Yen MY, Yen CM 2001. Eosinophilic meningitis caused by Angiostrongylus cantonensis: report of 17 cases. Am J Med 111: 109-114.

Wang QP, Lai DH, Zhu XQ, Chen XG, Lun ZR 2008. Human angiostrongyliasis. Lancet Infect Dis 8: 621-630.

Yousif F, Ibrahim A 1978. The first record of Angiostrongylus cantonensis from Egypt. Z Parasitenkd 56: 73-80. 